\title{
CORRESPONDENCE
}

\section{A MIDDLE WÜRM INTERSTADIAL IN SOUTH-WEST WALES--A REPLY TO G. S. BOULTON}

Sir, - I was interested to see the letter by G. S. Boulton in a recent issue of Geol. Mag. $(105,190-1)$. In his comments on my paper concerning the glacial deposits at Cil-maenllwyd, Cards. (Geol. Mag., 104, 630-3), he seems to have misunderstood me on a number of points and has unwittingly misrepresented me on others, and perhaps I may be permitted this reply.

Boulton appears to have gained the impression, after reading my paper, that I consider the Cil-maenllwyd pollen sample and the dated organic material $(33,750+2,500$ years

B.P.) to be of similar age. I do apologize if the title of my paper has given this impression, and I must admit here to a certain lack of precision in my abstract. But abstracts, by their very nature, are seldom precise or explicit ; and Boulton appears to have seized upon the wording of the abstract while omitting any real reference to the relevant parts of my text. If he looks again at the text he will find there several points which have a bearing on this discussion.

In his letter Boulton omits to mention that several of his points are already discussed (aibeit briefly) in my brief paper, while he credits me with statements and interpretations which I never made. In reply, the main points which spring to mind are as follows :-

1. On the matter of the pollen, Boulton devotes some space to proving that the assemblage in the Cil-maenllwyd sands is a mixed one derived from different sources. May I remind Dr. Boulton that I was quite aware of this fact? I refer in the paper to the presence of some reworked Carboniferous and Mesozoic spores and pollen in the sample, emphasizing that " the remains have come from a variety of different deposits of different ages" (page 633). I expected that this would prove to be an explicit enough statement on the origins of the pollen assemblage. Later, I suggest that " no speculations can be made concerning the age of most of the pollen from this sample" (page 633). I am, therefore, perfectly in agreement with Boulton when he says "John's pollen analysis is not evidence for a Mid-Würm interstadial . .." (page 191).

2. Boulton believes that my paper "unwittingly illustrates the difficulties of interpretation of derived plant material in glacial deposits" (page 190). Again, may I quote a point from the paper in reply? "Thus, the dating of glacial deposits by means of derived pollen involves the same risks as in dating by means of derived marine mollusca" (page 633). My illustration of these difficulties and risks was undertaken not quite as unwittingly as Dr. Boulton makes out.

3. Boulton seems to be intent upon proving that the Cil-maenllwyd sample used for $\mathrm{C}^{14}$ dating was probably contaminated, and makes several valid points concerning contamination. However, his attitude is entirely a negative one, and is not based upon any field evidence of contamination at the site in question. It would be as easy for me to cast doubt on any of the other radio-carbon dates from the British Pleistocene. Is it not just as likely that the Sandiway date (Boulton \& Worsley, 1965) or the Four Ashes dates (Shotton, 1967) are unreliable? And yet these authors interpret their dates in a straightforward manner, and draw their conclusions from them in the light of the evidence available. Does Dr. Boulton expect me to do otherwise with my $\mathrm{C}^{14}$ dates? Does he expect me to disbelieve the dates from West Wales and believe others ? I refuse to bury my head in the Cil-maenllwyd sands to quite this extent, and instead I have used the dates in support of a great deal of other evidence from West Wales (John, Oxford University Ph.D. thesis, 1965) to propose the hypothesis of a Middle Würm interstadial and a Main Würm glaciation in the area.

4. In a final point it is implied that because the Cil-maenllwyd date fits the current hypothesis, it should not necessarily be accepted. On the other hand, in view of the accumulating evidence at our disposal, I submit that there is even less reason to reject the date, as Boulton appears to have done. letter.

In addition to these larger issues, two small errors of fact have crept into Boulton's 
5. There is some inconsistency concerning the origin and age of the Cil-maenllwyd sands. Near the beginning of his letter Boulton attributes to me the suggestion that the kamiform sands of the Cil-maenllwyd and Banc-y-Warren complex were deposited during a "Middle Würm Interstadial". I made no such suggestion, and stated clearly (as Boulton recognizes later in his letter) that the sands were probably deposited during ice wastage at the end of a Main Würm glaciation.

6. The final paragraph of Boulton's letter suggests that the validity of the Cilmaenliwyd $C^{14}$ date is not improved by the existence of another date "from the same bed ". (Presumably he refers here to the Banc-y-Warren age determination of $31,800+1,400$ years B.P. presented by Brown et al., 1967.) May I point out first, that the Cil-maenllwyd and Banc-y-Warren samples were not obtained from the same bed, the same depth, or indeed from the same gravel-pit; and second, that there are two further age determinations from South-West Wales (John, 1965) and two from Lleyn (Saunders, 1968) which support the concept of a Middle Würm interstadial and a Main Würm glaciation of the Irish Sea-St. George's Channel area. Does Dr. Boulton consider that all of these samples could be "similarly contaminated"?

These points apart, Boulton and myself may share some common ground. There is, as he suggests, still a large measure of uncertainty concerning the climatic fluctuations of the Middle Würm in North-West Europe and the British Isles. No unequivocal indications have yet been found of fully boreal conditions at this time, and from the work of Van der Hammen et al. (1967), and Coope \& Sands (1966), one might assume that shrub tundra conditions marked the phase of greatest climatic amelioration in the period 43,000 to 29,000 years B.P. However, one would be foolish to assume that there is no more of the Middle Würm stratigraphic record to be discovered. If horizons from this interstadial are discovered in situ in the south-west approaches of Great Britain it will be interesting to see whether they bear any evidence of the limited afforestation which was in my mind during the writing of the paper.

Further, I agree that much more rigorous analysis of the organic material from the drifts of South-West Wales needs to be undertaken. When detailed pollen analyses and related studies of significant horizons have been completed, it should be possible either to confirm or reject the existing hypotheses for the events of the Würm. On the other hand, it will probably be many years before a reliable late Pleistocene chronology based upon co-ordinated palaeobotanical studies and radiocarbon dating is available, and in the meantime one can but speculate. I suggest that my speculations are based upon accumulated evidence from a variety of fields. But evidence rests in the eye of the beholder, and what is evidence to the present writer is obviously not evidence to Dr. Boulton. This is a normal enough situation, and one wishes that he could have recognized it as such. It may well be that the current hypotheses concerning the Würm in South-West Wales are unreliable. However, there is no evidence in Boulton's letter to reinforce this view, and I remain convinced that my interpretations are valid.

\section{REFERENCES}

Boulton, G. S. 1968. A Middle Würm interstadial in South-West Wales. Geol. Mag., 105, 190-1.

\& Worsley, P. 1965. Late Weichselian Glaciation in the Cheshire-Shropshire Basin. Nature, Lond., 207, 704-6.

Brown, M. J. F., Ellis-GrufFyd, I. D., Foster, H. D. \& Unwin, D. J. 1967. A new radiocarbon date for Wales. Nature, Lond., 213, 1220-1.

COOPE, G. R. \& SANDS, C. H. S. 1966. Insect faunas of the last glaciation from the Tame Valley, Warwickshire. Proc. Roy. Soc. Lond. B., 165, 389-412.

JoHN, B. S. 1965. A possible Main Würm glaciation in West Pembrokeshire Nature, Lond., 207, 622-3.

1967. Further evidence for a Middle Würm Interstadial and a Main Würm Glaciation of South-west Wales. Geol. Mag., 104, 630-3.

Saunders, G. E. 1968. Glaciation of Possible Scottish Readvance Age in NorthWest Wales. Nature, Lond, , 218, 76-8. 
Shotron, F. W. 1967. Age of the Irish Sea Glaciation of the Midlands. Nature, Lond., 215, 1366.

Van der Hammen, T., Maarleveld, G. C., Vogel, J. C. \& Zagwijn, W. H. 1967. Stratigraphy, climatic succession and radiocarbon dating of the Last Glacial in the Netherlands. Geologie Mijnb., 46, 79-95.

Department of Geography,

BRIAN S. JoHN.

SCIENCE Laboratories,

UNIVERSITY OF DURHAM.

24 th June, 1968.

\section{A NEW CLEANING TECHNIQUE FOR THE PREPARATION OF CALCAREOUS FOSSILS}

SIR,-The removal of adherent ferruginous material from calcareous fossils is often a difficult task. Examples of mechanical and chemical techniques are given by Franco (1947) ; Stevens, Jones \& Todd (1960) ; Kummel \& Raup (1965). Most of these treatments, however, though successful in some cases, often result in serious corrosion or cause physical disintegration of the sample. A survey has therefore been made of the comparative cleaning efficiency of a number of solvents, and, though no reagent was entirely satisfactory, the best results were obtained using chelating rust removers in an alkaline medium.

Acid Treatments.-Inorganic acids weak enough not to dissociate the carbonate failed to attack the iron oxides. Those acids tried included ortho-boric and telluric acid. The weakly acidic properties of phenol and substituted phenols suggested that they might prove satisfactory but no substantial solution of the oxide could be detected. Their use with an ultrasonic cleaner, however, gave results superior to those obtained using water alone, with ortho-cresol being the most efficient. Salicylic acid dissolved some of the oxides but resulted in attack of the carbonate-particularly on prolonged treatment. The di-sodium salts of E.D.T.A. buffered to a $\mathrm{pH} 6.6$ with phosphates gave a similar result.

Alkaline Treatments.-In alkaline conditions NN di ( 2 hydroxy ethyl) glycine was tried with limited success and a better result was obtained using alkali gluconate in saturated alkali solution. Sodium gluconate is readily available and its solution in saturated caustic soda was therefore tested first. Much of the iron oxide was removed with this reagent but the carbonate was also attacked. An equivalent potassium solution produced even greater etching of the carbonate surfaces investigated. The lithium anologue was therefore made, by adding an excess of lithium hydroxide to glucono-deltalactone, and the application of this reagent provided satisfactory solution of the oxide with minimal carbonate etching. It therefore seems likely that lithium gluconate in an aqueous saturated lithium hydroxide solution may prove a useful addition to the range of reagents suitable for fossil preparation.

Procedure.-The reagent is prepared by dissolving glucono-delta-lactone $(5 \mathrm{~g})$ in distilled water $(50 \mathrm{ml})$, warming gently for $10 \mathrm{~min}$ at about $35^{\circ} \mathrm{C}$ to allow hydrolysis to the acid to take place, and then adding lithium hydroxide $(14 \mathrm{~g})$ and diluting to $100 \mathrm{ml}$ with distilled water.

The sample, which if delicate may be suspended in a nylon net bag, is boiled in the reagent for about $30 \mathrm{~min}$, washed and brushed in water and finally rinsed in acetone. The specimens used for trials were echinoid spines from Faringdon sponge gravel and from the Red Crag lamellibranchs. Several pure minerals, including haematite, chalybite, limonite and pyrite were treated and little or no attack was observed. Treatment of a ferruginous calc-arenite showed that some shell types were cleaned and others not.

\section{REFERENCES}

Franco, R. 1947. Notes on techniques in invertebrate palaeontology. J. Paleont., 21, 396-9.

Kummel, B. \& Raup, D. 1965 . Handbook of Palaeontological Techniques, p. 273-5 (W. H. Freeman \& Co., San Francisco and London). 